\title{
Severity of Bacterial Leaf spot (Xanthomonas axonopodis pv. vignaeradiatae) of Green gram in Different Tehsils of Udaipur District, Rajasthan
}

\author{
Jitendra Kumar* and Anila Doshi
}

Department of Plant Pathology, Rajasthan College of Agriculture, MPUAT, Udaipur-313001, India

A B S T R A C T

\begin{tabular}{|l|l|l|}
\hline Keywords & $\begin{array}{l}\text { Bacterial leaf spot bacterium (Xanthomonas axonopodis pv. } \\
\text { vignaeradiatae) of green gram caused considerable damage every year } \\
\text { Green gram, } \\
\begin{array}{l}\text { Bacterial leaf spot, } \\
\text { Per cent disease } \\
\text { index, Survey }\end{array}\end{array}$ & $\begin{array}{l}\text { heavy loss in grain yield. The maximum mean per cent disease index was } \\
\text { observed in Vallabhnagar followed by Kotra, Mavli, Jhadol, Gogunda, }\end{array}$ \\
\hline Article Info & $\begin{array}{l}\text { Salumber Tehsil and least percent disease index was observed at Kherwara } \\
\text { Tehsil of Udaipur districts during surveys in the years i.e. 2013 and }\end{array}$ \\
\hline $\begin{array}{l}\text { Accepted: } \\
\text { A February 2018 } \\
\text { 10 March } 2018\end{array}$ & $\begin{array}{l}\text { 2014.The per cent disease index varied from 07.56 - 32.60 and 08.56 - } \\
\text { 29.42 in the years 2013 and 2014, respectively. The overall disease severity } \\
\text { was more in 2013 as compared to 2014. }\end{array}$ \\
\hline \hline
\end{tabular}

\section{Introduction}

Green gram [Vigna radiata (L.) Wilczek] is one of the important pulse crop in India, which has been cultivated since ancient times. It is widely cultivated throughout the Asia, including India, Pakistan, Bangladesh, Sri Lanka, Thailand, Cambodia, Indonesia, Malaysia and south China. In India, it is grown over on an area of 34.4 lac hectares with a production of 14 lac tones and with average productivity $406.98 \mathrm{~kg} / \mathrm{ha}$. The major growing states of green gram are Rajasthan (30.81\%), Maharashtra (19.51\%), Karnataka (15.35\%), Andhra Pradesh (12.79\%), Orissa (7.41\%), Tamil Nadu (4.97\%) and Uttar
Pradesh (2.09\%), respectively (Anon., 2014a). In Rajasthan, it is cultivated on 8.93 lac hectares with production of 4.23 lac tones. The major growing districts are Nagaur, Jodhpur, Pali, Jaipur, Udaipur, Chittorgarh, Banswara and Barmer (Anon., 2014b).

Green gram is well suited to a large number of cropping system and a popular cereal-based diets due to easily digestible, rich in protein $(25-28 \%)$, oil $(1.0-1.5 \%)$, fiber $(3.5-4.5 \%)$, ash $(4.5-5.5 \%)$ and carbohydrates (62-65\%) on dry weight basis (Singh et al., 2010). Green gram is more palatable, nutritive, digestible and non-flatulent than other pulses (Anjum et $a l ., 2006)$. It not only plays an important role 
in human diet but also in improving the soil fertility by fixing the atmospheric nitrogen (Muhammad et al., 2004). Inadequate nutrient status of soil is a particular problem for small landholders of the developing countries, where much grain-legume production occurs (Peter and Vance, 2003).

Green gram plant suffers from two bacterial disease namely, bacterial leaf spot and halo blight (Pseudomonas syringae pv. phaseolicola). Out of these two diseases the former is economically more important and widespread in India (Thind, 2012). Bacterial leaf spot pathogen produces symptoms on leaves, stems, pods and seeds. Small watersoaked spots are the initial symptoms observed on leaves and appear within 4 to 10 days of infection. These spots enlarge and the centre turns necrotic and brown, areas around the lesion may become flaccid. The lesion is surrounded by a narrow band of bright yellow tissue; stem infection is less common and begins as a water-soaked spot, which becomes reddish-brown and usually without chlorosis. Stem girdling may develop at the cotyledonary node (Patel and Jindal, 1972; Chand, 1986).

Bacterial leaf spot caused by Xanthomonas axonopodis pv. vignaradiatae (Vauterin et al., 1995) is an important seed borne disease and frequently causes considerable reduction in yield and economic loss to the growers. The pathogen is disseminated to new areas through infected seeds (Shekhawat and Patel, 1977), whereas local spread occurs through spattering rains (Chand, 1986). It has assumed considerable importance as it becomes destructive and devastative particularly under favourable environmental conditions.

Soni and Thind (1991) detected bacterial pathogen of green gram from seeds by using bacteriophages. The bacterium was detected in shrivelled and discoloured seeds. The pathogen was identified as. Xanthomonas campestris pv. vignaradiatae. Patro (2004) reported leaf spot as serious problem of green gram cultivation both in India and elsewhere. Seed and soil borne organisms singly or in combination caused the seedling disease complex of this crop resulting in partial or complete loss of crop stand. Annual yield loss due to bacterial leaf spot ranged from $5-25 \%$, but under severe infection on highly susceptible variety yield loss gone up to $100 \%$.

Thind (2012) described symptoms of bacterial leaf spot of green gram. The symptoms of leaf spot were in the form of brown, circular to irregular and raised spots. Generally the spots were dry and necrotic from the beginning of their formation but sometimes they were water soaked or had translucent border. They appeared on either surface as superficial eruption but gradually developed through the entire thickness of the leaflet and become corky and rough. The disease did not cause defoliation and dark cankers were developed and often extending from soil level to the growing tips. Lesions on the pods were brown raised but were seen rarely in nature. Disease had been found on all parts of green gram plants. As the pathogen is largely parenchymatous, infected plants are not completely killed. However, severe infections results in the necrosis of considerable leaf area leading to the reduction in photosynthesis and general weakening of the plants.

\section{Materials and Methods}

Survey's were conducted to know the distribution and prevalence of bacterial leaf spot of green gram during the kharif season of 2013-14 and 2014-15 in green gram growing areas of Udaipur district, which includes Tehsil viz., Mavli, Vallabhnagar, Gogunda, Jhadol, Kherwara, Kotra and Salumber. The disease severity in the plants was recorded at 30 days after sowing till maturity stage by 
randomly selecting five spots in every field and closely examining 20 plants in each of the four directions of the selected point. Severity of disease in a field was recorded as percentage of lesion area infected out of total leaf area examined.

The Typical symptoms of bacterial leaf spot of green gram on cotyledons, stem, pods and leaves are described in Figure 2. The disease situation for each plant was noted on an arbitrary scale of 0-5.

The disease rating key was used based on leaf spot disease development in which infected plants were categorized in arbitrary classes. Natural symptoms of disease were recorded during this period. The disease severity was recorded by using the following scale (Rathore, 2006).

The entire data were pooled together and per cent disease index was calculated by using following formula (Wheeler, 1969).

Sum of individual disease ratings Per cent disease index $=-\mathrm{x} 100$

Total no. of plants leaves assessed $\mathrm{x}$ Maximum disease rating

\section{Results and Discussion}

An intensive survey to record the disease severity were carried out for consecutive two years during Kharif 2013 and 2014 in major green gram growing areas of Mavli, Vallabhnagar, Gogunda, Jhadol, Kherwara, Kotra and Salumber Tehsil of Udaipur district to estimate the disease prevalence.

The per cent disease index for green gram bacterial leaf spot disease was noticed in all the locations surveyed ranging from 5.50 to 38.36 and 7.30 to 34.60 PDI in the year 2013 and 2014, respectively which indicates its distribution and occurrence in large areas. It was observed that average disease severity was more between 30 to 60 days old crop. The severity data also indicate that the disease initiation was at 20-30 days after sowing (Fig. $1)$.

In the year 2013, the maximum mean per cent disease index (38.36) was observed in Sarjana village of Vallabhnagar Tehsil followed by Bhatewar (36.90 PDI), Jura (28.46 PDI), Dabok (26.40 PDI), Bikarni (24.03 PDI), Akodara (22.55 PDI), Amli (19.29 PDI), Jaswantgarh (18.56 PDI), Phalasiya (18.05 PDI), Mavli (17.80 PDI), Amaliya (16.87 PDI), Cheetarawas (16.78 PDI), Mandwa (16.60 PDI), Jhadol (14.55 PDI), Devgaon (12.50 PDI), Saradi (11.46 PDI, Sundara (10.50 PDI), Semar (09.23 PDI), Thana (06.68), Jaitpura (06.70 PDI) and least percent disease index was observed at Badla village (05.50 PDI) (Table 1).

In the year 2014, the maximum mean per cent disease index (34.60) was observed in Bhatewar village of Vallabhnagar Tehsil followed by Sarjana (29.36), Mavli (26.80 PDI), Jura (26.46 PDI), Akodara (24.30 PDI), Mandwa (22.70 PDI), Jaswantgarh (19.50 PDI), Amli (19.20 PDI), Cheetarawas (17.80 PDI), Bikarni (17.40 PDI), Jaitpura (16.40 PDI), Amaliya (15.80 PDI), Phalasiya (14.60 PDI), Dabok (14.40 PDI), Semar (12.28 PDI), Jhadol (12.00 PDI), Devgaon (10.60 PDI), Sundara (09.50 PDI), Saradi (07.30 PDI), Badla (05.50 PDI) and least percent disease index was observed at Thana (07.40 PDI) (Table 2).

On the basis of Tehsil wise mean data, in the year 2013, maximum per cent disease index (32.60 PDI) was recorded in Vallabhnagar Tehsil followed by Kotra (23.03 PDI), Mavli (21.16 PDI), Jhadol (16.49 PDI), Gogunda (14.85 PDI), Salumber (10.22 PDI) and least PDI was observed at Kherwara Tehsil (07.56 PDI). 


\section{Disease rating scale of leaf spot of green gram}

\begin{tabular}{|c|c|}
\hline 0 & No infection \\
\hline 1 & Minute water soaked spots scattered over the leaves covering about $1-10 \%$ leaf area. \\
\hline 2 & Little bigger spots covering about $10-25 \%$ leaf area. \\
\hline 3 & $\begin{array}{l}\text { Bigger leaf spot covering about } 25-50 \% \text { leaf area, few small spots on petiole and } \\
\text { stem initiated. }\end{array}$ \\
\hline 4 & $\begin{array}{l}\text { About } 50-75 \% \text { leaf area covered by heavy necrotic spotting, distinct enlarged } \\
\text { elliptical lesion on petiole and stem. }\end{array}$ \\
\hline 5 & $\begin{array}{l}\text { Above } 75 \% \text { leaf area covered with necrotic leaf spots, cracking of stem, leaf spot or } \\
\text { infection on pods. }\end{array}$ \\
\hline
\end{tabular}

Table.1 Distribution and prevalence of bacterial leaf spot of green gram at different locations of Udaipur district during Kharif season of 2013

\begin{tabular}{|c|c|c|c|c|c|}
\hline Tehsil & $\begin{array}{l}\text { Name of the } \\
\text { village }\end{array}$ & $\begin{array}{c}\text { Cultivars/ } \\
\text { Variety }\end{array}$ & Crop stage & $\begin{array}{c}\text { Area } \\
\text { (ha) }\end{array}$ & $\begin{array}{l}\text { Mean per cent } \\
\text { disease index } \\
\text { (PDI) }\end{array}$ \\
\hline \multirow[t]{4}{*}{ Mavli } & Mavli & RMG-62 & Grand growth stage & 2.00 & $17.80(24.94)^{*}$ \\
\hline & Dabok & SML-668 & Flowering stage & 1.50 & $26.40(30.90)$ \\
\hline & Amli & RMG-62 & Grand growth stage & 2.00 & $19.29(26.04)$ \\
\hline & Mean & & & & 21.16 \\
\hline \multirow[t]{4}{*}{ Vallabhnagar } & Akodara & SML-668 & Grand growth stage & 1.50 & $22.55(28.34)$ \\
\hline & Sarjana & GM-4 & Flowering stage & 0.50 & $38.36(38.26)$ \\
\hline & Bhatewar & SML-668 & Flowering stage & 2.00 & $36.90(37.39)$ \\
\hline & Mean & & & & 32.60 \\
\hline \multirow[t]{4}{*}{ Gogunda } & Jaswantgarh & SML-668 & Maturity stage & 1.50 & $18.56(25.50)$ \\
\hline & Semar & Local & Pod formation stage & 0.50 & $09.23(17.67)$ \\
\hline & Cheetarawas & GM-4 & Maturity stage & 2.00 & $16.78(24.17)$ \\
\hline & Mean & & & & 14.85 \\
\hline \multirow[t]{4}{*}{ Jhadol } & Phalasiya & RMG-268 & Pod formation stage & 1.50 & $18.05(25.13)$ \\
\hline & Jhadol & RMG-62 & Grand growth stage & 3.00 & $14.55(22.41)$ \\
\hline & Amaliya & Local & Pod formation stage & 1.50 & $16.87(24.24)$ \\
\hline & Mean & & & & 16.49 \\
\hline \multirow[t]{4}{*}{ Kherwara } & Badla & Local & Flowering stage & 0.50 & $05.50(13.55)$ \\
\hline & Thana & $\mathrm{K}-851$ & Flowering stage & 1.00 & $06.68(14.97)$ \\
\hline & Sundara & Local & Pod formation stage & 2.00 & $10.50(18.90)$ \\
\hline & Mean & & & & 07.56 \\
\hline \multirow[t]{4}{*}{ Kotra } & Mandwa & Local & Pod formation Stage & 1.25 & $16.60(24.03)$ \\
\hline & Bikarni & SML-668 & Maturity stage & 0.25 & $24.03(29.34)$ \\
\hline & Jura & RMG-62 & Maturity stage & 2.00 & $28.46(32.17)$ \\
\hline & Mean & & & & 23.03 \\
\hline \multirow[t]{4}{*}{ Salumber } & Jaitpura & Local & Pod formation stage & 1.50 & $06.70(14.99)$ \\
\hline & Saradi & SML-668 & Maturity stage & 0.50 & $11.46(19.78)$ \\
\hline & Devgaon & Local & Maturity stage & 0.75 & $12.50(20.41)$ \\
\hline & Mean & & & & 10.22 \\
\hline SEm \pm & & & & & 0.4155 \\
\hline CD at $5 \%$ & & & & & 1.1594 \\
\hline CV\% & & & & & 5.38 \\
\hline
\end{tabular}

* Figures in the parenthesis are arc sin transformed values 
Table.2 Distribution and prevalence of bacterial leaf spot of green gram at different locations of Udaipur district during Kharif season of 2014

\begin{tabular}{|c|c|c|c|c|c|}
\hline Tehsil & $\begin{array}{l}\text { Name of the } \\
\text { village }\end{array}$ & $\begin{array}{l}\text { Cultivars/ } \\
\text { Variety }\end{array}$ & Crop stage & $\begin{array}{l}\text { Area } \\
\text { (ha) }\end{array}$ & $\begin{array}{c}\text { Mean per cent } \\
\text { disease index (PDI) }\end{array}$ \\
\hline \multirow[t]{4}{*}{ Mavli } & Mavli & RMG-62 & Maturity stage & 1.00 & $26.80(31.17)^{*}$ \\
\hline & Dabok & Local & Flowering stage & 0.50 & $14.40(22.29)$ \\
\hline & Amli & Local & Pod formation stage & 2.00 & $18.20(25.24)$ \\
\hline & Mean & & & & 19.80 \\
\hline \multirow[t]{4}{*}{ Vallabhnagar } & Akodara & Local & Grand growth stage & 1.50 & $24.30(29.52)$ \\
\hline & Sarjana & GM-4 & Flowering stage & 2.50 & $29.36(32.75)$ \\
\hline & Bhatewar & Local & Flowering stage & 2.00 & $34.60(35.95)$ \\
\hline & Mean & & & & 29.42 \\
\hline \multirow[t]{4}{*}{ Gogunda } & Jaswantgarh & SML-668 & Maturity stage & 1.50 & $19.50(26.19)$ \\
\hline & Semar & Local & Pod formation stage & 2.50 & $12.28(20.50)$ \\
\hline & Cheetarawas & GM-4 & Maturity stage & 2.00 & $17.80(24.94)$ \\
\hline & Mean & & & & 16.52 \\
\hline \multirow[t]{4}{*}{ Jhadol } & Phalasiya & RMG-268 & Pod formation stage & 1.50 & $14.60(22.45)$ \\
\hline & Jhadol & RMG-62 & Grand growth stage & 2.25 & $12.00(20.25)$ \\
\hline & Amaliya & Local & Pod formation stage & 1.50 & $15.80(23.41)$ \\
\hline & Mean & & & & 14.13 \\
\hline \multirow[t]{4}{*}{ Kherwara } & Badla & Local & Flowering stage & 2.00 & $08.80(17.25)$ \\
\hline & Thana & Local & Flowering stage & 0.50 & $07.40(15.77)$ \\
\hline & Sundara & SML-668 & Pod formation stage & 2.00 & $09.50(17.94)$ \\
\hline & Mean & & & & 08.56 \\
\hline \multirow[t]{4}{*}{ Kotra } & Mandwa & Local & Pod formation Stage & 1.25 & $22.70(28.44)$ \\
\hline & Bikarni & Local & Flowering stage & 0.50 & $17.40(24.64)$ \\
\hline & Jura & RMG-62 & Maturity stage & 1.00 & $26.46(30.82)$ \\
\hline & Mean & & & & 22.18 \\
\hline \multirow[t]{4}{*}{ Salumber } & Jaitpura & Local & Pod formation stage & 2.50 & $16.40(23.76)$ \\
\hline & Saradi & SML-668 & Flowering stage & 0.75 & $07.30(15.67)$ \\
\hline & Devgaon & Local & Flowering stage & 2.00 & $10.60(18.99)$ \\
\hline & Mean & & & & 11.43 \\
\hline SEm \pm & & & & & 0.5099 \\
\hline CD at $5 \%$ & & & & & 1.4229 \\
\hline CV\% & & & & & 6.67 \\
\hline
\end{tabular}

* Figures in the parenthesis are arc sin transformed values 
Fig.1 Distribution and prevalence of bacterial leaf spot of green gram at different locations of Udaipur district during Kharif season, 2013 and 2014

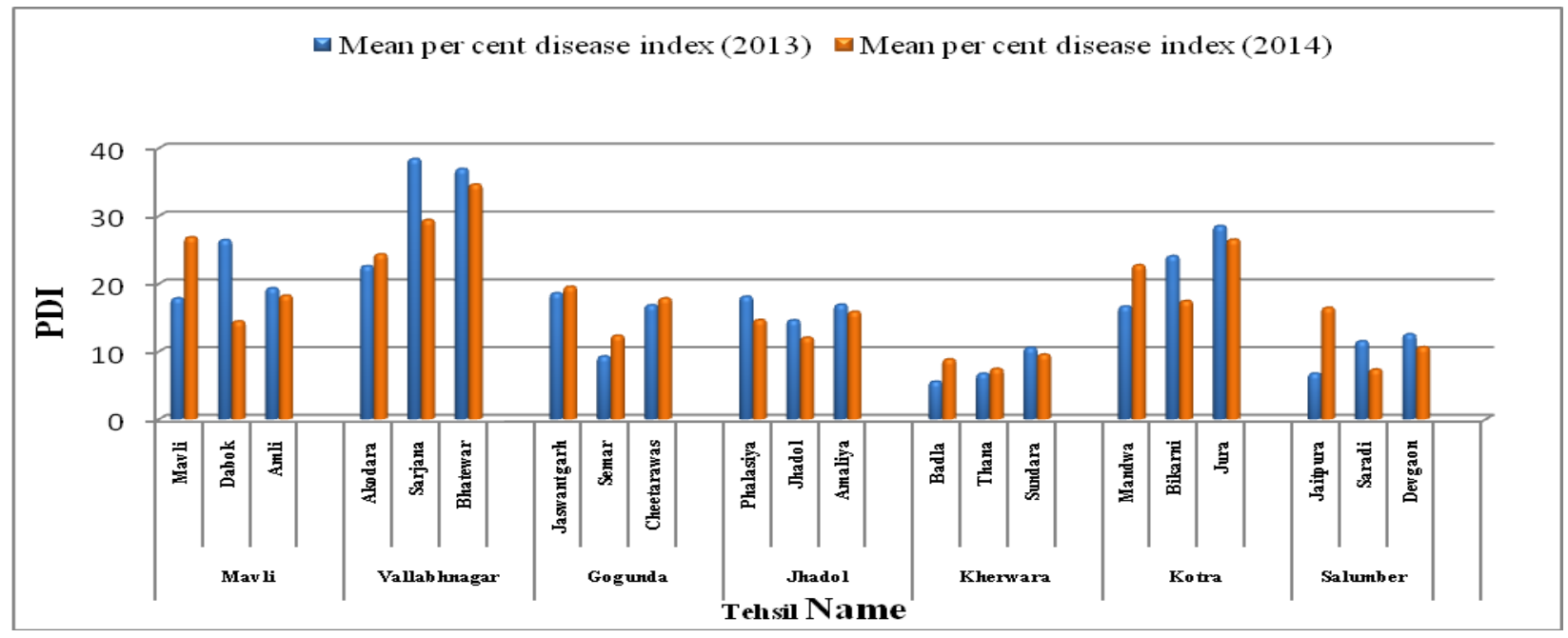

Fig.2 Typical symptoms of bacterial leaf spot of green gram on cotyledons, stem, pods and leaves



Dark brown lesions on stem

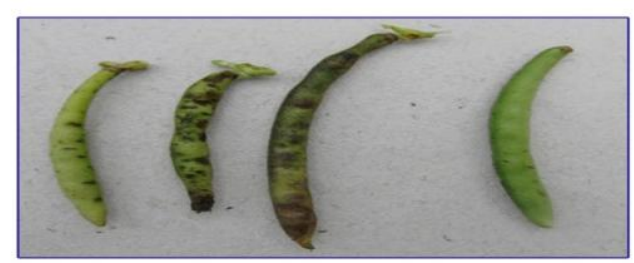

Dark brown spots on pods

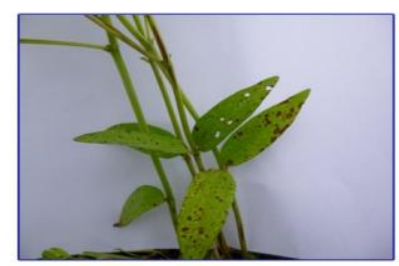

Shot hole and brown spots


Chocolaty necrotic patches in vascular region

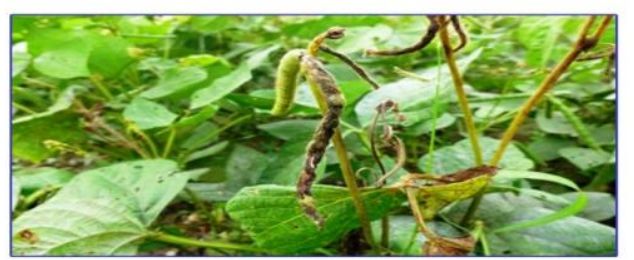

Deformed pods
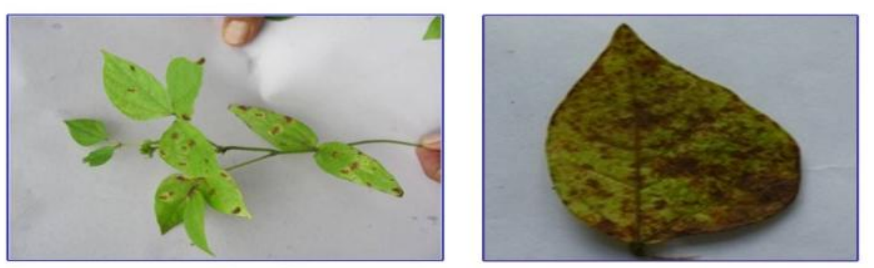

Brown spots with yellow margin Corky symptoms on old leaves 
During survey in Kharif 2014, similar pattern of disease occurrence was recorded from all these location with maximum per cent disease index (29.42 PDI) in Vallabhnagar Tehsil followed by Kotra (22.18 PDI), Mavli (19.80 PDI), Gogunda (16.52 PDI), Jhadol (14.13 PDI), Salumber (11.43 PDI) and least PDI was observed at Kherwara Tehsil (08.56 PDI). From this survey it was observed that this disease was severe and appears in damaging form during Kharif, 2013. Whereas, disease severity was reduced during Kharif 2014. From these studies it can be predicted that environmental factors are critical for occurrence and spread of disease in epidemic form (Table 1 and 2).

Survey for occurrence and distribution of disease was necessary because there are very limited published reports and records are available on this disease in Rajasthan. However, it was cultivated in wide area in Rajasthan but it is a kind of glimpse of the loss it causes due to this disease. The disease incidence varied from locality to locality, because of cropping pattern, environmental conditions, use of different varieties and buildup of inoculum load. It was observed during the survey that incidence of disease was negligible up to July. This clearly indicated that the disease intensity depends on factors like location, cultural practices followed by use of infected seeds of susceptible variety, improper drainage and meteorological factors like temperature, relative humidity and rainfall.

In general, it was observed that disease incidence was maximum during July-August which coincides with heavy rains and cloudy weather. During survey it has been observed that Bacterial leaf spot incidence was more in Kharif season i.e., wherever rainfall was more during the season. The disease incidence was more because of suitable environmental parameters for development of the pathogen. Incidence of the disease was less wherever improved varieties were used and early sowing has been practiced indicating the importance of proper selection of cropping season and disease free seeds helping in managing bacterial leaf spot disease of green gram.
From survey's, in Kharif season of 2013 and 2014 it has been found that bacterial leaf spot incidence was present in almost all Tehsil wherever the green gram was cultivated. The disease severity was highest in Vallabhnagar and Mavli whereas, it was less in Kherwara Tehsil of Udaipur district, Rajasthan. In the years 2013, there was more rainfall as compared to 2014 in all the locations surveyed in Udaipur district.

Interestingly, there were 2-3 spells of heavy rains which caused heavy disease severity in 2013. The per cent disease index ranges varied from 5.50 to 38.36 and 7.30 to 34.60 in the both years i.e. 2013 and 2014, respectively. Hence, disease severity ranges indicate that favorable climate and infected seeds are important factors of disease.

Similar observations were made by Patro (2004), who reported the bacterial leaf spot of green gram caused by $X$. axonopodis $\mathrm{pv}$. vignaeradiatae and opined that the pathogen was carried within the seed and spreads in the field by moisture propelled wind. Annual yield loss due to bacterial leaf spot ranged from 5$25 \%$, but under severe infection on highly susceptible variety yield loss gone up to $100 \%$.

Rathore (2010) reported the occurrence of leaf spot on green gram caused by $X$. axonopodis $\mathrm{pv}$. vignaeradiatae in Jodhpur, Rajasthan for the first time during Kharif season 2006 as circular, necrotic, corky leaf spots, surrounded by a thin water soaked hallow on green gram plants with an incidence of 6.1 to 24.9 PDI at various stages of infection in different green gram cultivars substantiating the results of the present survey wherein incidence varied from genotype to genotype.

\section{Acknowledgement}

The authors are highly grateful to the higher authorities of the University and other faculty members for facilitating required needs as well as rendering moral support during the entire research work. 


\section{References}

Anjum, M. S., Ahmed, Z. I. and Rauf, C. A. 2006. Effect of Rhizobium inoculation and nitrogen fertilizer on yield and yield components of mungbean. International Journal of Agriculture \& Biology. 8: 238240.

Anonymous, 2014a. Annual report for the year 2013-2014. Department of agriculture and cooperation, Ministry of agriculture, Government of India, Krishi Bhawan, New Delhi, Pp. 20-47.

Anonymous, 2014b. Rajasthan Agriculture statistics at a glance for the 2013-2014. Directorate of agriculture, Rajasthan, Jaipur. Pp, 74-75, 83.

Chand, J. N. 1986. Bacterial disease of legume and their management. Indian Journal of Mycology and Plant Pathology. 30: 1921.

Muhammad, A. N., Rashid, A. and Ahmad, M. S. 2004. Effect of seed inoculation and different fertilizer levels on the growth and yield of mungbean (Vigna radiata L.). Journal of Agronomy. 3: 40-42.

Patel, P. N. and Jindal, J. K. 1972. Bacterial leaf spot and halo blight disease of mungbean and other legume in India. Indian Phytopathology.25: 526-529.

Patro, T. S. S. K. 2004. Plasmid-borne determinant of antibiosis in phylloplane Bacillus sp. associated with mungbean against bacterial leaf spot. Journal of Plant Protection. 32: 96-99.
Peter, H. G. and Vance, C. P. 2003. Legumes: importance and constraints to greater use. Plant Physiology. 131: 872-877.

Rathore, B. S. 2006. Efficacy of streptocycline and plant extracts against bacterial leaf spot disease caused by Xanthomonas axonopodis pv. Vignae radiatae of green gram. Indian Phytopathology.63: 384386.

Rathore, B. S. 2010. Efficacy of streptocycline and plant extracts against bacterial leaf spot greengram. Journal of mycology and plant pathology. 36: 153-156.

Shekhawat, G. S. and Patel, P. N. 1977. Seed transmission and spread of bacterial blight of cowpea and mungbean and leaf spot of green gram summer and monsoon season. Plant Disease Reporter. 61: 390392.

Singh, B. B., Dixit, G. P. and Katiyar, P. K. 2010. Vigna research in India. All India Coordinated Research Project on MULLaRP, IIPR, Kanpur.Pp.1.

Soni, P. S. and Thind, B. S. 1991. Detection of Xanthomonas campestris pv. vignae radiatae (Sabet et al.,) Dye from green gram seeds and $X$. campestris $p v$. vignicola (Burkh.) Dye from cowpea seeds with the help of bacteriophages. Plant Dis. Res. 6: 6-11.

Thind, B. S. 2012. Phytopathogenic prokaryotes and plant diseases. Scientific Publishers, Jodhpur. Pp.134, 401-470.

Wheeler, B. E. J. 1969. An introduction to plant diseases. John Willey and Sons Ltd., London. Pp. 301.

\section{How to cite this article:}

Jitendra Kumar and Anila Doshi. 2018. Severity of Bacterial Leaf Spot (Xanthomonas axonopodis pv. vignaradiatae) of Green Gram in Different Tehsils of Udaipur District, Rajasthan, India. Int.J.Curr.Microbiol.App.Sci. 7(03): 2924-2931. doi: https://doi.org/10.20546/ijcmas.2018.703.338 